\title{
In vitro digestibility and predicted glycemic index of commonly consumed some Turkish traditional foods
}

\author{
Sabiha Zeynep Aydenk KOSEOGLU (D), Seda CELIKEL² (1)
}

\begin{abstract}
This study was planned to determine in vitro glycemic indices of some traditional foods frequently consumed by Turkish nation and to evaulate their effects on nutrition. Glycemic indices of roasted chickpea, Turkish bagel, tarhana, bulgur, Turkish delight, baklava, pişmaniye and kadayıf species; white bread was taken as reference (70) and analyzed in vitro by taking digestive system model. Glycemic index of Turkish bagels and bulgur was high $(>70)$, medium $(55-70)$ of tarhana and low $(<55)$ of roasted chickpea. There was a significant relationship between the hydrolysis indices of Turkish Delight and other sweet foods and also glycemic indices $(\mathrm{p}<0.05)$. Absorption rates of all foods increased and reached the highest level in parallel with their hydrolysis indices after 3 hours. Turkish delight had the highest RAG (glucose released from starch and sugars within 20 min incubation), while RAG and RDS (rapidly digestible starch) of the roasted chickpea were low. Chickpeas with the lowest glycemic index according to their digestibility and effects on blood glucose should be recommended by nutrition professionals to provide glycemic control and controlled consumption of the delight with the highest glycemic index.
\end{abstract}

Keywords: glycemic index; glycemic control; tradiational foods; in vitro; digestibility rate; hydrolysis index.

Practical Application: This study was planned to determine in vitro glycemic indices of some traditional foods frequently consumed by Turkish nation and to evaulate their effects on nutrition.

\section{Introduction}

Geography, economic conditions and customs, traditions established in the society can be effective in the differentiation of foods used in nutrition according to countries (Demirbaş et al., 2006). Turkey has about 2,500 traditional foods known. As in all cultures, traditional foods are frequently consumed and it is thought that consumption in our country will accelerate in recent years and will continue to increase in the future (Onurlubaş \& Taşdan, 2017). Most of these commonly used traditional foods consist of foods rich in simple carbohydrates.

Glycemic index (GI); definition was first introduced by Jenkins et al. (1981), and different foods containing the same amount of carbohydrates may have different blood glucose effects (Köseoğlu, 2019). Food and Agriculture Organization/World Health Organization (FAO/WHO) determines the GI value of foods by comparing the blood glucose increase area that is formed within 2 hours after consumption and absorption of the test food containing $50 \mathrm{~g}$ digestible carbohydrate to the glucose increase area formed by the same amount of carbohydrate reference food. G1 reference ranges of foods were accepted as $\leq 55$ low, 56-69 medium and $\geq 70$ high GI (Mann et al., 2007; Topbaş Bıyıklı et al., 2017).

Glycemic control is important in the treatment and control of diabetes and consumption of low GI-containing carbohydrates is the main approach (Livesey et al., 2019). High GI foods; increase the plasma glucose in the systemic circulation rapidly and cause sudden and irregular insulin response. High GI diets stimulate pancreatic beta cells to induce insulin dysfunction due to irregular and intense release of insulin in these cells; impaired rhythm of insulin secretion and in peripheral cells; loss of insulin receptors can cause resistance to insulin (Pfeiffer \& Keyhani-Nejad, 2018; Pereira et al., 2004). Glycemic control is vital for healthy eating as well as diabetes mellitus.

Presence of fat and proteins in foods, effects of types and amounts on glycemia may be different (Lilly et al., 2019). Proteins increase insulin secretion and reduce the digestion rate of starch, while fats extend the transition time of the food from the stomach to the small intestine and reduce GI by forming a complex structure with starch (Köksal, 2008).

Apart from these, starch species in the structure of foods, monosaccharide content, fiber, maturity and acidity, nutrient inhibitors, health status of individuals and so on. other factors affecting glycemic index (Baysal et al., 2008).

FAO/WHO standardized the analysis of the GI value of foods by in vivo methods. However, in vivo methods are more disadvantageous in terms of time and cost than in vitro methods. The basis of the in vitro glycemic index method is based on the measurement of carbohydrate digestibility. This system is carried out with the enzymes of the mouth, stomach and small

1 Department of Nutrition and Dietetics, Faculty of Health Sciences, Istanbul Sabahattin Zaim University, Istanbul, Turkey

${ }^{2}$ Department of Nutrition and Dietetics, Faculty of Health Sciences Bayburt University, Bayburt, Turkey

*Corresponding author: szaydenk@gmail.com 
intestine at appropriate temperature and $\mathrm{pH}$ environment for a certain period of time.

Hydrolysis index; The hydrolysis curve of the tested food between $0-120 \mathrm{~min}$ or $0-180 \mathrm{~min}$ is obtained by comparing the hydrolysis curve of white bread which is the reference food. The estimated glycemic index, is calculated by placing the HI (hydrolysis index) value into the formula previously obtained by Goni or Granfeldt in correlation of in vivo and in vitro methods (Goñi et al., 1997).

Although traditional carbohydrate-based foods are consumed a lot, there is not enough information about their glycemic index in Turkey. The aim of this study is to determine by in vitro method the glycemic index of some traditional foods that are frequently consumed and to examine the effects on nutrition and health. In line with the obtained results, the way to be followed in the consumption of these foods that are studied is determined.

\section{Materials and methods}

\subsection{Materials}

Glucose, fructose, sucrose, methanol, ethanol, potassium hydroxide $(\mathrm{KOH})$, sodium acetate pepsin (from porcine gastric mucosa, $250 \mathrm{U} / \mathrm{mL}$ ), pancreatin (from porcine pancreas, $8 \times \mathrm{USP}$ specifications) and guar gum were taken from Sigma-Aldrich Co., LLC. (St. Louis, MO, USA). Invertase (from yeast, $300 \mathrm{U} / \mathrm{mL}$ ), thermostable $\alpha$-amylase (from Bacillus licheniformis, $3000 \mathrm{U} / \mathrm{mL}$ ), amyloglucosidase (from aspergillus niger, $3330 \mathrm{U} / \mathrm{mL}$ ) and glucose oxidase-peroxidase (GOPOD) regent were obtained from Megazyme (Wicklow, IRELAND).

\subsection{Samples}

In this research, 8 different the most commonly consumed traditional foods (roasted chickpea, bagel, tarhana, bulgur, Turkish delight, baklava, pişmaniye, kadayıf) were provided from different markets in Istanbul, Turkey. The detailed nutritional composition of traditional foods included in this study is given in Table 1 and the data are taken from Turkomp (2020).

\subsection{Starch determination of traditional foods}

The starch content of the samples was determined using the method created by Goñi et al. (1997) with some changes. $0.1 \mathrm{~g}$ of sample was weighed in a $50 \mathrm{~mL}$ plastic Falcon tube and vortexed by adding $0.2 \mathrm{~mL}$ of aqueous ethanol $(80 \%, \mathrm{v} / \mathrm{v})$ to ensure dispersion. Then $2 \mathrm{~mL}$ of $2 \mathrm{M} \mathrm{KOH}$ solution was added and mixed with magnetic bar $(5 \times 15 \mathrm{~mm})$ for 20 minutes in an ice/water bath. Then, $8 \mathrm{~mL}$ of $1 \mathrm{M}$ sodium acetate solution (pH 3.8) was added, followed by $0.1 \mathrm{~mL}$ of heat-resistant a-amylase and $0.1 \mathrm{~mL}$ of amyloglucosidase. Incubated at $50{ }^{\circ} \mathrm{C}$ for 30 minutes, cooled to room temperature, adjusted to $50 \mathrm{~mL}$ with deionized water and centrifuged at $4000 \mathrm{xg}$ for 10 minutes. $0.1 \mathrm{~mL}$ of sample was placed in a $10 \mathrm{~mL}$ glass tube and $3.0 \mathrm{~mL}$ of GOPOD reagent was added. Incubated for 30 minutes at $50{ }^{\circ} \mathrm{C}$ in water bath. Absorbance in spectrophotometer (UV-1280, Shimadzu) was measured at $510 \mathrm{~nm}$.

\subsection{In vitro starch digestibility}

In vitro starch digestibility was made by Englyst et al. (1992) with some modifications. The bioaccessibility of the starch was studied using an in vitro human digestive system. This model includes the mouth, stomach, and small intestinal medium.

\subsection{Digestive enzymes and other solutions}

Enzymes for digestion were prepared as follows:

Enzyme Solution 1 (Pepsin/Guar Gum Solution): $0.5 \mathrm{~mL}$ of peptide and $0.5 \mathrm{~g}$ of guar gum were added to a $100 \mathrm{~mL}$ bottle with $0.05 \mathrm{~N} \mathrm{HCl}$ solution and mixed with a magnetic stir bar. The volume was then adjusted with $0.05 \mathrm{~N} \mathrm{HCl}$.

Enzyme Solution 2 (for one example - pancreatin $(136 \mathrm{mg} / \mathrm{mL}$ ), amyloglucosidase $(13.4 \mathrm{U} / \mathrm{mL})$ and invertase $(25.43 \mathrm{U} / \mathrm{mL}))$ were used. For each sample, $680 \mathrm{mg}$ of pancreatin was weighed in a $50 \mathrm{~mL}$ falcon tube and mixed with $4 \mathrm{~mL}$ of deionized water. It was centrifuged at $2000 \mathrm{x}$ g for 10 minutes. The residue was then discarded and $67 \mathrm{U}$ amyloxidaseidase and $127.15 \mathrm{U}$ invertase were added to the upper phase, and the volume was adjusted to $5 \mathrm{~mL}$ with deionized water. $1 \mathrm{gr}$ sample, homogenized, was weighed in $250 \mathrm{~mL}$ erlenmeyer, $5 \mathrm{~mL}$ deionized water, $10 \mathrm{~mL}$ freshly prepared enzyme solution 1 and 5 glass balls were added. The proteins were incubated horizontally at $37^{\circ} \mathrm{C}$ in a shaking water bath (175 strokes/minute) for 30 minutes to hydrolyze with pepsin. The $\mathrm{pH}$ was then adjusted to 5.2 by adding $0.5 \mathrm{M}$ sodium acetate solution $(5 \mathrm{~mL})$.

Enzyme Solution $2(5 \mathrm{~mL})$ was added and the volume was adjusted to $50 \mathrm{~mL}$ with deionized water. During incubation

Table 1. The detailed nutritional composition of traditional foods included in this study.

\begin{tabular}{|c|c|c|c|c|c|c|c|c|c|c|}
\hline & Energy & Protein & Fat & $\mathrm{CHO}$ & Fiber & Starch & Saccharose & Maltose & Glucose & Fructose \\
\hline & (kcal) & (g) & (g) & (g) & (g) & (g) & $(\mathrm{g})$ & (g) & (g) & (g) \\
\hline Baklava & 432 & 5.53 & 22.64 & 48.26 & 6.63 & 12.59 & 10.14 & 0 & 6.44 & 5.5 \\
\hline Bulgur & 357 & 12.08 & 3.95 & 64.97 & 6.79 & - & - & - & - & - \\
\hline Kadayıf & 314 & 8.78 & 2.44 & 62.63 & 3.02 & 50.26 & - & - & - & - \\
\hline Roasted Chickpea & 395 & 21.56 & 7.53 & 54.43 & 11.7 & 40.76 & - & - & - & - \\
\hline Turkish Delight & 359 & 0.13 & 0.19 & 89.28 & 0 & 11.8 & 24.95 & 0 & 20.92 & 20.41 \\
\hline Pişmaniye & 454 & 3.53 & 12.29 & 82.43 & - & 27.99 & 42.39 & 1.64 & 4.28 & 2.24 \\
\hline Bagel & 368 & 12.14 & 16.46 & 38.42 & 8.94 & 28.77 & - & - & - & - \\
\hline Tarhana & 317 & 14.38 & 3.06 & 54.92 & 6.15 & 55.7 & - & - & - & - \\
\hline
\end{tabular}

Turkomp (Accessed 20 January 2020). 
in a shaking water bath at $37^{\circ} \mathrm{C}, 0.5 \mathrm{~mL}$ sample was taken at $20,30,60,90,120$ and 180 minutes and placed in a $10 \mathrm{~mL}$ glass tube. It was left in the hot water bath for 5 minutes to denature the enzymes. The sample was passed to a $15 \mathrm{~mL}$ plastic falcon tube, and the volume was completed to $5 \mathrm{~mL}$. It was centrifuged for 5 minutes. Then the glucose amount was determined as in starch analysis.

The types of starch fractions were determined as follows:

TS: Total starch, $T S=(T G-F G) \times 0.9$;

RDS: Rapidly digestible starch, $R D S=(G 20-F G) \times 0.9$;

RS: Resistant starch, $R S=T S-(R D S+S D S)$;

RAG: Glucose released from starch and sugars within 20 min incubation;

AG: Glucose released from starch and sugars within 120 min incubation.

The estimated glycemic index was calculated using HI values of each sample. HI was obtained by dividing the area under the hydrolysis curve of the test sample by the area obtained for white bread. Then, the estimated glycemic index was calculated by applying the formula defined by Goñi et al. (1997): $\mathrm{GI}=39.71+0.549$. HI.

\subsection{Statistical analysis}

Statistical analysis was done with SPSS 25 programme. The distribution of the data was evaluated according to the normality test result, and the T-Test and Anova tests independent of parametric tests, Kruskal Wallis and Mann-Whitney U tests, which are non-parametric tests, were used. In the significance test, $\mathrm{p}$ value is based on 0.05 with $95 \%$ confidence interval. All analyses were performed three times, and the average value was used. Significant differences between the applications were statistically evaluated using one-way analysis of variance (ANOVA p $<0.05$, Tukey's test).

\section{Results and discussion}

The products were divided into 2 separate groups: salty traditional foods and sweet traditional foods.

When the bagel, roasted chickpea, bulgur and tarhana, which are salty traditional foods in Table 2, are examined among themselves; When the glycemic indices of tarhanas with bagel, roasted chickpeas and bulgur were compared, a significant relationship was found respectively $(\mathrm{p}=0.026, \mathrm{p}=0.009, \mathrm{p}<0.05)$. Comparing the glycemic indices of chickpeas with bagels and bulgur, a significant relationship was found respectively $(\mathrm{p}=0.001$, $p=0.001$ ). When the bagels and bulgur were compared in terms of their glycemic index, there was no statistically significant relationship between them ( $\mathrm{p}>0.05)$.

In Table 3, when the sweet traditional foods, kadayif, pişmaniye, Turkish delight and baklava are evaluated according to their glycemic indexes;
When the glycemic indexes of kadayifs with Turkish delight and baklava were compared, a significant relationship was found respectively $(\mathrm{p}=0.002, \mathrm{p}=0.015)$. When kadayıf and pismaniye were compared in terms of glycemic indexes, no statistically significant relationship was found between them ( $p>0.050)$. When the glycemic indexes of Turkish delights with pişmaniye and baklava were compared, a significant correlation was found respectively $(\mathrm{p}=0.007, \mathrm{p}=0.001)$. When the pişmaniye and baklava were compared, no statistically significant relationship was found between them ( $\mathrm{p}>0.05)$.

According to the GI classification, while the traditional glycemic index of Turkish bagels and bulgur is high, the tarhana is medium, and the roasted chickpeas are low, the sweetness of the traditional foods is high, with a kadayıf and a pişmaniye, the glycemic index is high, and the other kadayif and pişmaniye types and baklava have a high glycemic index. respectively.

When the products are evaluated in terms of digestibility according to Table 4 and Table 5; Compared to the traditional RAG value of salty foods, no significant difference was found in

Table 2. Glycemic index values of salty traditional foods.

\begin{tabular}{ccc}
\hline $\begin{array}{c}\text { Salty Traditional } \\
\text { Foods }\end{array}$ & Glycemic Index & $\begin{array}{c}\text { GI Ratio of Foods Compared } \\
\text { to White Bread }\end{array}$ \\
\hline Bagel 1 & $103.6 \pm 0.9$ & 76.9 \\
Bagel 2 & $103.1 \pm 1.0$ & 76.6 \\
Bagel 3 & $98.8 \pm 1.3$ & 73.4 \\
Roasted Chickpea 1 & $66.4 \pm 1.3$ & 49.3 \\
Roasted Chickpea 2 & $66.2 \pm 1.0$ & 49.1 \\
Roasted Chickpea 3 & $68.8 \pm 0.8$ & 51.1 \\
Bulgur 1 & $100.2 \pm 1.7$ & 74.4 \\
Bulgur 2 & $102.6 \pm 1.0$ & 76.2 \\
Bulgur 3 & $100.8 \pm 1.3$ & 74.8 \\
Tarhana 1 & $87.8 \pm 1.9$ & 65.2 \\
Tarhana 2 & $79.5 \pm 1.2$ & 59.0 \\
Tarhana 3 & $93.5 \pm 1.3$ & 69.4 \\
White Bread & $94.2 \pm 0.4$ & 70.0 \\
\hline
\end{tabular}

Average value was used $(n=3)$,

Table 3. Glycemic index values of sweet traditional foods.

\begin{tabular}{ccc}
\hline $\begin{array}{c}\text { Sweet Traditional } \\
\text { Foods }\end{array}$ & Glycemic Index & $\begin{array}{c}\text { GI Ratio of Foods Compared } \\
\text { to White Bread }\end{array}$ \\
\hline Kadayıf 1 & $94.0 \pm 1.9$ & 69.8 \\
Kadayıf 2 & $89.3 \pm 1.7$ & 66.3 \\
Kadayıf 3 & $95.0 \pm 1.9$ & 70.5 \\
Pişmaniye 1 & $92.1 \pm 1.8$ & 68.4 \\
Pişmaniye 2 & $86.5 \pm 1.6$ & 64.2 \\
Pişmaniye 3 & $100.2 \pm 2.1$ & 74.4 \\
Turkish Delight 1 & $112.2 \pm 2.5$ & 83.3 \\
Turkish Delight 2 & $121.4 \pm 2.9$ & 90.2 \\
Turkish Delight 3 & $120.1 \pm 2.8$ & 89.2 \\
Baklava 1 & $77.0 \pm 0.5$ & 57.2 \\
Baklava 2 & $82.4 \pm 1.0$ & 61.2 \\
Baklava 3 & $84.4 \pm 1.0$ & 62.7 \\
White Bread & $94.2 \pm 0.4$ & 70.0 \\
\hline Average value was used $(\mathrm{n}=3)$ &
\end{tabular}

Average value was used $(n=3)$. 
Table 4. Digestibility levels of salty traditional foods.

\begin{tabular}{|c|c|c|c|c|}
\hline Salty Traditional Foods & RAG & $\mathrm{AG}$ & RDS & TG \\
\hline Bagel 1 & $0.187 \pm 0.004$ & $0.218 \pm 0.003$ & $0.168 \pm 0.004$ & $0.551 \pm 0.00$ \\
\hline Bagel 2 & $0.190 \pm 0.005$ & $0.196 \pm 0.009$ & $0.171 \pm 0.005$ & $0.533 \pm 0.00$ \\
\hline Bagel 3 & $0.204 \pm 0.007$ & $0.189 \pm 0.012$ & $0.183 \pm 0.007$ & $0.584 \pm 0.00$ \\
\hline Roasted Chickpea 1 & $0.075 \pm 0.006$ & $0.088 \pm 0.013$ & $0.067 \pm 0.006$ & $0.524 \pm 0.00$ \\
\hline Roasted Chickpea 2 & $0.073 \pm 0.006$ & $0.099 \pm 0.001$ & $0.065 \pm 0.006$ & $0.544 \pm 0.00$ \\
\hline Roasted Chickpea 3 & $0.079 \pm 0.005$ & $0.109 \pm 0.003$ & $0.071 \pm 0.005$ & $0.550 \pm 0.00$ \\
\hline Bulgur 1 & $0.116 \pm 0.004$ & $0.097 \pm 0.003$ & $0.104 \pm 0.004$ & $0.334 \pm 0.00$ \\
\hline Bulgur 2 & $0.094 \pm 0.004$ & $0.090 \pm 0.004$ & $0.084 \pm 0.004$ & $0.269 \pm 0.00$ \\
\hline Bulgur 3 & $0.122 \pm 0.003$ & $0.106 \pm 0.006$ & $0.109 \pm 0.003$ & $0.335 \pm 0.00$ \\
\hline Tarhana 1 & $0.123 \pm 0.006$ & $0.179 \pm 0.012$ & $0.110 \pm 0.006$ & $0.541 \pm 0.00$ \\
\hline Tarhana 2 & $0.107 \pm 0.004$ & $0.211 \pm 0.008$ & $0.096 \pm 0.004$ & $0.699 \pm 0.00$ \\
\hline Tarhana 3 & $0.121 \pm 0.006$ & $0.182 \pm 0.006$ & $0.108 \pm 0.006$ & $0.504 \pm 0.00$ \\
\hline White Bread & $0.187 \pm 0.003$ & $0.428 \pm 0.003$ & $0.168 \pm 0.003$ & $0.642 \pm 0.00$ \\
\hline
\end{tabular}

Average value was used $(n=3)$.

Table 5. Digestibility levels of sweet traditional foods.

\begin{tabular}{ccccc}
\hline Sweet Traditional Foods & RAG & AG & RDS & TG \\
\hline Kadayıf 1 & $0.284 \pm 0.010$ & $0.629 \pm 0.022$ & $0.284 \pm 0.010$ & $0.762 \pm 0.000$ \\
Kadayıf 2 & $0.274 \pm 0.010$ & $0.578 \pm 0.020$ & $0.274 \pm 0.010$ & $0.785 \pm 0.000$ \\
Kadayıf 3 & $0.281 \pm 0.010$ & $0.660 \pm 0.023$ & $0.281 \pm 0.010$ & $0.801 \pm 0.000$ \\
Pişmaniye 1 & $0.330 \pm 0.012$ & $0.574 \pm 0.020$ & $0.330 \pm 0.012$ & $0.792 \pm 0.000$ \\
Pişmaniye 2 & $0.324 \pm 0.011$ & $0.511 \pm 0.018$ & $0.324 \pm 0.011$ & $0.759 \pm 0.000$ \\
Pişmaniye 3 & $0.467 \pm 0.016$ & $0.706 \pm 0.025$ & $0.467 \pm 0.016$ & $0.751 \pm 0.000$ \\
Turkish Delight 1 & $0.650 \pm 0.023$ & $0.758 \pm 0.027$ & $0.650 \pm 0.023$ & $0.707 \pm 0.000$ \\
Turkish Delight 2 & $0.696 \pm 0.024$ & $0.877 \pm 0.031$ & $0.696 \pm 0.024$ & $0.723 \pm 0.000$ \\
Turkish Delight 3 & $0.721 \pm 0.025$ & $0.825 \pm 0.029$ & $0.721 \pm 0.025$ & $0.742 \pm 0.000$ \\
Baklava 1 & $0.202 \pm 0.003$ & $0.379 \pm 0.005$ & $0.202 \pm 0.003$ & $0.717 \pm 0.000$ \\
Baklava 2 & $0.191 \pm 0.005$ & $0.385 \pm 0.008$ & $0.191 \pm 0.005$ & $0.585 \pm 0.000$ \\
Baklava 3 & $0.195 \pm 0.004$ & $0.382 \pm 0.009$ & $0.195 \pm 0.004$ & $0.631 \pm 0.000$ \\
White Bread & $0.187 \pm 0.003$ & $0.428 \pm 0.003$ & $0.168 \pm 0.003$ & $0.642 \pm 0.000$ \\
\hline
\end{tabular}

Average value was used $(n=3)$.

bulgur and tarhana, and borderline significance was observed among all other groups $(\mathrm{p}=0.050)$.

There was no significant difference between sweet traditional foods in terms of RAG among themselves ( $p>0.050$ ). According to Spearman correlation analysis, there was no negative or positive correlation between total starch and glycemic index.

The digestibility percentage of salty traditional foods examined in Figure 1 is given over time. The bagel has the highest digestibility and roasted chickpea is the lowest; Among the sweet traditional foods examined in Figure 2, Turkish delight has the highest digestibility and the pişmaniye is the lowest. The digestibility of all products increases over time.

Bulgur according to the Turkish Food Codex; It is a foodstuff obtained by refining, soaking, cooking, drying, adjusting the moisture level to ensure easy shelling, peeling, crushing, screening processes of wheat (Turkey, 2009c: 2009/24).

Since bulgur is produced without any chemical process, it is natural and superior in terms of nutritional value compared to other grains with its high pulp content, and it is known as a source of low glycemic index and rich in folic acid and B group vitamins. In the cooking process during production; starch combines with nitrogenous substances and a hard structure is formed with the contribution of heat (Kenar, 2016).

In the production of bulgur, which is one of the traditional foods, during the grinding of the bran layer, it prevents the loss of B vitamins caused by the separation of bran (Baysal, 2018; Kemahlioğlu \& Demirağ, 2010). This ensures that bulgur is rich in vitamins and minerals as well as being a high-fiber food. In the first 20 minutes of the analysis of the bulgur examined in this study, the glucose released from starch and sugars, that is, the RAG values, were found to be low (bulgur1 $0.116 \pm 0.004$, bulgur2 $0.094 \pm 0.004$, bulgur3 $0.112 \pm 0.003$ ). At the end of the first 20 minutes, bulgur is digested on average $35 \%$ of carbohydrates, and after 180 minutes, on average $73 \%$ is digested. The glycemic indices of bulgur and white bread were similar. The fact that the bulgur used was boiled and that no oil was added could be the cause of the high glycemic index. It is estimated that the glycemic index may be lower in cooking methods made with the addition of oil or when cooked with protein-containing foods. 


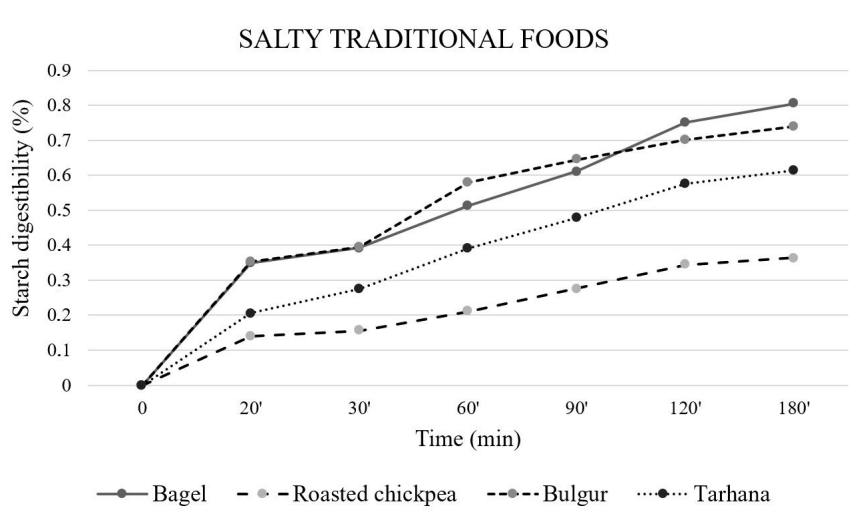

Figure 1. The mean of glucose concentration of salty traditional foods from digestible carbohydrates between 20-180 minutes.

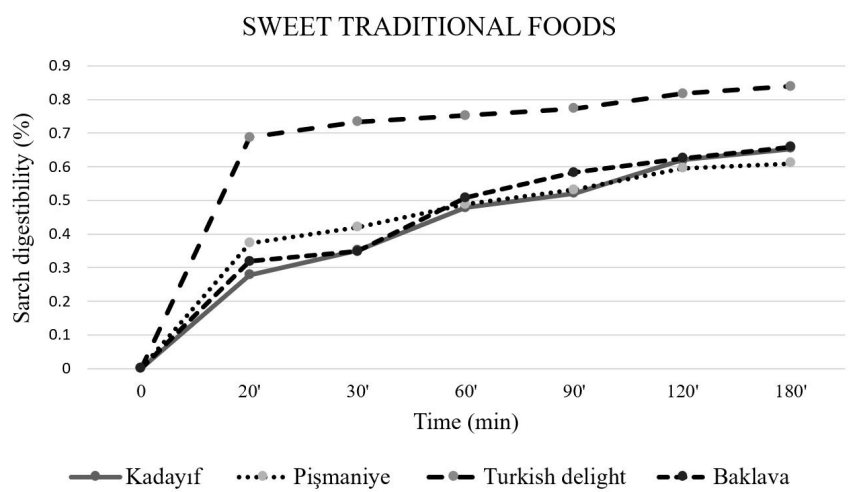

Figure 2. Themean of glucose concentration of sweet traditional foods from digestible carbohydrates between 20-180 minutes.

Roasted chickpea, a chickpea derivative that can be consumed in the form of sugary and salty snacks except for fresh use; It has an important place in nutrition due to its protein, vitamin and mineral content. Chickpeas have an average protein content of 47-53\% (Nestares et al., 1996).

Among all the traditional products examined, roasted chickpea has the lowest glycemic index. The rate of fast digestible starch (HSN) is lower than other products (roasted chickpea $1=0.067 \pm 0.006$, roasted chickpea $2=0.065 \pm 0.006$, roasted chickpea $3=0.071 \pm 0.005$ ), and the rate of resistant starch (RS) is higher. At the end of the 180th minute, an average of $36 \%$ of roasted chickpeas is absorbed in the small intestine medium prepared in vitro. This rate was found significantly lower than white bread. Since the digestible carbohydrate ratio in roasted chickpea is low, its effect on blood glucose will be slower and longer. Due to this feature, it is an ideal food for diabetes patients who want to keep blood glucose in balance. In addition, roasted chickpea has a cholesterol-lowering effect as it is a product obtained from chickpeas. Although the glycemic index of the traditional plain roasted chickpea examined in this study is low, it is estimated that the glycemic index of the roasted chickpeas covered with foods such as sugar, honey, sesame, poppy and chocolate will be different.
In a study, the contents of wheat, roasted corn and chickpea nuts, total dietary fiber, soluble/insoluble pulp, fast/slow digestible starch, resistant starch and rapidly usable glucose contents and the hydrolysis index of starch were determined. It has been observed that the moisture content of all nuts are low (1.2-4.2\%), high protein (8.8-20.9\%), moderate fat (1.3-11.3\%) and high carbohydrate (70.5-84.3\%) foods. These foods were rich in total dietary fiber (9.2-21.9\%), insoluble fiber (7.1-19.1\%) and soluble fiber $(2.1-4.4 \%)$. According to the results of the study, it was determined that chickpea nuts had lower starch digestion rates and rates than corn and wheat nuts. A significant correlation $(r=0.90, p<0.01)$ was determined between the fast usable glucose ratios of the nuts (15.9-59.4\%) and the starch hydrolysis index (20.1-81.7). All nuts have been found to be low-fat and high-fiber, slow-digesting food compared to corn chips (Sayaslan et al., 2016).

According to the definition of the Turkish Standards Institute tarhana; It is a nutrient with high nutritional value obtained by kneading vegetable products such as tomato, onion, salt, wheat flour, semolina, flavoring, pepper and yoghurt together, leaving them for fermentation and then drying, grinding and sieving (Türk Standartları Enstitüsü, 2004).

Tarhana was found to be higher in glycemic index and lower than bagels and bulgur compared to roasted chickpeas in traditional salty foods. The rate of rapidly digestible starch (RDS) was lower than the rate of slow digestible starch. In the analysis, $61 \%$ of tarhana can be absorbed at the end of 180 minutes. This prevents the rapid and excessive increase of blood glucose. The protein content of yogurt used in the production of tarhana causes its glycemic index to be low. Due to its rich nutrient content, Tarhana is an ideal food that can be preferred in complementary feeding, especially in infants (Aksoydan, 2005; Topal et al., 2016). It is also considered that it may have probiotic properties as it undergoes fermentation process (Baysal, 2018; Baysal et al., 2020). Since fermented foods have a cholesterol-lowering effect and keep the blood cholesterol level stable due to the fiber contained in tarhana, it is an effective food in lowering the risk of colon cancer (Özdemir et al., 2007).

100 grams of sesame used in the production of simit contains an average of $16.81 \mathrm{~g}$ of protein and $51.20 \mathrm{~g}$ of oil. The amino acids and fatty acids found in sesame seeds have important functions in the use of micronutrients in the body, in the functioning of immunity, energy and hormone mechanisms and in the repair of some tissues by supporting growth and development (www.türkomp.com; Ayaz, 2008).

Turkish bagel, because of the high fat content of sesame used in its production, the ejaculation time of the stomach is extended and the formation of a feeling of hunger is delayed (Ayaz, 2008). As the molasses used in bagel production consists of glucose and fructose, it can be consumed as an ideal nutrient in the urgent energy need of the body (Baysal, 2018). However, due to the simple sugars it contains, it has been found to be the food with the highest glycemic index among the salty traditional foods in the study. At the end of the 180th minute of in vitro analysis performed in this study, an average of $80 \%$ of bagels are absorbed. The bagels were found to have higher glucose (RAG) values than other salty traditional foods. In other words, since 
the glucose levels released from starch and sugars are higher in the 20th minute, blood glucose rises rapidly after the bagel consumption.

Kadayıf is a semi-finished product obtained by pouring the liquid dough prepared by adding drinking water to the sifted wheat flour according to its technique, mixing it and frying when necessary (Türk Standartları Enstitüsü, 2010). Kadayıf is offered to the market in two types, roasted or not roasted. Kadayif, which was produced in small enterprises until recently, is produced in large enterprises (Pekak, 2006).

Kadayif production consists of 4 stages: dough kneading, dough beating, shaping and baking. The characteristics of the flour used in the production of kadayif are quite different from other special purpose flours. In the production of kadayif, low gluten and gluten index (60\%) flour and low protein content are preferred (Turkey, 2009a).

Low sedimentation value, low gluten content and low protein soft wheat are preferred in the production of kadayif flour (Turkey, 2009b).

Wheat varieties required for kadayif flour are among soft wheats with low protein quality and quantity. Hard wheat with high protein content will increase starch damage during the milling process (Pekak, 2006).

An average of $65 \%$ of the raw kadaylf, one of the sweet traditional foods, are absorbed at the end of the 180th minute. Total starch (TS) and total glucose (TG) ratio was found to be the highest among other sweet traditional foods and the lowest rate of resistant starch (RS). This situation may affect the duration of hunger sensation after consumption. In the kadayif types examined in the study, sherbet (boiled sugar water poured over traditional Turkish sweets) and oil were not used. However, when kadayif is consumed as sweet, GI values are expected to be higher. When sherbet is added and consumed as dessert; In liver diseases, hyperlipidemias, risk of obesity, careful consumption is important in planning the nutrition program.

Pişmaniye is a traditional product produced in accordance with its method by adding sugar, wheat flour, butter, margarine or sunflower oil, when necessary, additives and flavoring components according to the standard (Türk Standartları Enstitüsü, 2014).

An average of $60 \%$ of the pişmaniye, one of the sweet traditional foods, are absorbed at the end of the 180th minute. The rate of rapidly available glucose (RAG) compared to other sweet traditional foods; It is low compared to Turkish delight and higher than kadayıf and baklava. Since its energy value is high, it can be inconvenient to use it frequently in cases where weight control is required and in the treatment of diseases where body fat is high.

Turkish Food Codex Turkish Delight Communique; It is described as a product prepared in accordance with its method by adding flavoring substances to the Turkish delight mass prepared with sugar, starch, water and citric acid or tartaric acid/potassium bitartarate. According to this communiqué, the total amount of sugar in terms of sucrose must be at least 75\% by mass in dry matter (Turkey, 2013: 2013/55).
Turkish delight has been one of Anatolia's popular traditional confectionery products since the 15 th century. It takes its name from the word "rahat ul-hulküm", which means "relieve your throat" in Ottoman. It is a jelly-like candy based on starch and sugar gel and is one of the oldest desserts in the World (Gönül, 1985; Doğan, 2008).

Turkish delights has been found to be the food with the highest glycemic index among all traditional foods examined in this study. In the analysis of Turkish delights, it was concluded that an average of $68 \%$ at the end of the first 20 minutes and an average of $83 \%$ at the end of 180 minutes could be absorbed. This is due to the high digestible carbohydrate ratio. Turkish delight was found higher in the first 20 minutes after consumption compared to other sweet traditional foods in terms of the rapidly available glucose (RAG) released from all sugars and the total amount of available glucose (AG) released in the 120th minute.

There are very limited studies about Turkish delight in literatüre and little attention has been paid to the enrichment of this product with the use of fresh wet fruits.

Turkish delight, which we find as a food with high glycemic index, has been tried to reduce the glycemic index value and energy ratio by using the method of reducing the sugar rate in some studies. In one of these studies, different formulations were studied in the laboratory environment by adding substances such as xanthan gum, guar gum, xylitol, aspartame, acesulfame- $\mathrm{K}$ in different proportions in order to provide the desired taste and dense texture by reducing the amount of starch and sugar in the main formulation of Turkish delights. Turkish delights with reduced energy values produced with these formulations were evaluated in terms of appearance and texture and a suitable method was tried to be found. According to the results of the sequencing test of the study, two formulations containing $0.5 \%$ guar gum and $0.6 \%$ ksatan gum were preferred together with sugar, starch and water, and the two formulas in which aspartame and acesulfame-K were mixed in equal proportions to create the desired taste. It has been found to be preferred in terms of. In the research, Turkish delights were produced according to the traditional production methods of 4 different companies, and the compressibility values of the Turkish delights samples measured with the instron were measured at $0.110 .09-0.60 \mathrm{~kg} / \mathrm{mm}$ for four different companies in the 1st, 2 nd and 3rd months, respectively; $0.19-0.17-0.83 \mathrm{~kg} / \mathrm{mm} ; 0.09-0.08-0.39 \mathrm{~kg} / \mathrm{mm}$; It has been found in the range of $0.19-0.12-0.80 \mathrm{~kg} / \mathrm{mm}$. The total sugar content of the same products in dry matter is $84.16 \%$, respectively, according to different companies; $88.75 \%$; 77.12\%; It was found to be $77.76 \%$. The starch values of plain Turkish delight samples are $12.96 \% ; 9.27 \% ; 17.57 \%$; It was determined to be $17.48 \%$. The compressibility values of the two energy-reduced Turkish delight formulations, measured by instron, are 1., 2. 0.23-0.11-0.19 in the first formulation in the 3rd and 3rd months, respectively; In the second formulation, it was found $0.20-0.14-0.14$, and the total sugar amounts were found to be $77.73 \%$ and $77.72 \%$ in dry matter (Kaftan, 2002).

Turkish Baklava recipe according to TSE standards: Hard wheat flour or dough produced from a mixture of flour, salt, egg and water produced for special purposes; rolling the dough according to the method by sprinkling starch obtained from 
hard wheat; After adding cream, butter or saturated butter, pistachios, walnuts, hazelnuts or almonds according to the type; It is described as a product with added sherbet, which is obtained by adding the additives approved in the legislation, slicing, cooking at the appropriate time and temperature and boiling sugar with water (lemon juice or lemon salt is added). According to the Turkish baklava standard, the sugar used must be white sugar (Türk Standartları Enstitüsü, 2015).

Baklava has been found to have the highest resistant starch and lowest fast digestible starch ratios among other sweet traditional foods studied in this study. Low glycemic index compared to other sweet traditional foods can be attributed to high fat content. In vitro environment, it has been determined that $65 \%$ of baklava can be absorbed in 180 minutes. It should not be frequently included in our daily diet, especially since the high content of fat and sugar in and it can cause health problems.

\section{Conclusion}

In the study, among the traditional foods taken from different sales centers, the lowest glycemic index was found as roasted chickpea and the highest was Turkish delight. The glycemic index in traditional foods with added fat and protein was determined to be lower than those without.When the Turkish delight with high glycemic index is examined in vitro, the amount of fast digestible glucose from all sugars in the first 20 minutes was found to be quite high.For this reason, while recommending delight in people with impaired glucose tolerance and insulin resistance, the amount of consumption should be taken into consideration and it should be recommended to consume foods containing protein and or fat following consumption.

Due to the low glycemic index of the roasted chickpea, it is suitable to be used in the mid-meal and for people who need weight control in order to achieve glycemic control, especially in people who are undergoing a medical nutrition program.

\section{Acknowledgements}

We thank the İstanbul Sabahattin Zaim University for their support.

\section{References}

Aksoydan, E. (2005). Yaşlılık ve beslenme. Ankara: TC Sağlık Bakanlığı, Başkent Üniversitesi, Burgaz Matbaası.

Ayaz, A. (2008). Yağhl tohumların beslenmemizdeki yeri (Sağlık Bakanlığ Yayın, No. 727). Ankara: Sağlık Bakanlığı.

Baysal, A. (2018). Beslenme (18. baski). Ankara: Hatiboğlu Yayınevi.

Baysal, A., Aksoy, M., Besler, H. T., Bozkurt, N., Keçecioğlu, S., Merdol, T. K., \& Yıldız, E. (2020). Diyet El Kitabı (12. baskı, pp. 67-143). Ankara: Hatipoğlu Yayınevi.

Demirbaş, N., Oktay, D., \& Tosun, D. (2006). AB sürecindeki Türkiye'de gıda güvenliği acısından geneleksel gidaların üretim ve pazarlaması. Harran Üniversitesi Ziraat Fakültesi Dergisi, 10(3-4), 47-55.

Doğan, I. S. (2008). Turkish delight production with raw materials and problems. Electronic Journal of Food Technologies, 1, 13-17.
Englyst, H. N., Kingman, S. M., \& Cummings, J. H. (1992). Classification and measurement of nutritionally important starch fractions. European Journal of Clinical Nutrition, 46(Suppl. 2), S33-S50. PMid:1330528.

Goñi, I., Garcia-Alonso, A., \& Saura-Calixto, F. (1997). A starch hydrolysis procedure to estimate glycemic index. Nutrition Research, 17(3), 427-437. http://dx.doi.org/10.1016/S0271-5317(97)00010-9.

Gönül, M. (1985). A research on Turkish delight making technique (1st ed., Ege University Publication, No. 8). Izmir, Turkey: Ege University Publiction. (in Turkish).

Jenkins, D. J., Wolever, T. M., Taylor, R. H., Barker, H., Fielden, H., Baldwin, J. M., Bowling, A. C., Newman, H. C., Jenkins A. L., \& Goff, D. V. (1981). Glycemic index of foods: a physiological basis for carbohydrate exchange. The American Journal of Clinical Nutrition, 34(3), 362-366.

Kaftan, A. (2002). Kalorisi Düşürülmüş lokum üretiminde bazı katkı maddelerinin kullanılabilirliğinin araştırılması (Yüksek Lisans Tezi). Ege Üniversitesi, İzmir.

Kemahlioğlu, K., \& Demirağ, K. (2010). İzmir Piyasasında Tüketime Sunulan Bazı Bulgurların Türk Gıda Kodeksi Bulgur Tebliği ile Türk Standartları Enstitüsü Bulgur Standardı'na Uyumlarının Karşılaştırılması. Akademik Gıda, 8(4), 29-34.

Kenar, S. (2016). Tarihinden Tarifine: Bulgur (2. baski). Istanbul: Duru Bulgur Yayınevi.

Köksal, G. (2008). Glisemik indeks ve glisemik yükün kardiovasküler hastalıkların tıbbi beslenme tedavisindeki yeri ve etkinliği. TK Merdol (konuk ed), Türk Kardiyoloji Seminerleri, 8(2), 194-205.

Köseoğlu, S. Z. A. (2019). A comparison of blood glucose and insulin responses in subjects with non-insulin dependent diabetes mellitus consuming potato alone, and potato with sunflower oil. Avrupa Bilim ve Teknoloji Dergisi, (15), 440-449.

Lilly, L. N., Heiss, C. J., Maragoudakis, S. F., Braden, K. L., \& Smith, S. E. (2019). The effect of added peanut butter on the glycemic response to a high-glycemic index meal: a pilot study. Journal of the American College of Nutrition, 38(4), 351-357. http://dx.doi.org/10.1080/073 15724.2018.1519404. PMid:30395790.

Livesey, G., Taylor, R., Livesey, H. F., Buyken, A. E., Jenkins, D., Augustin, L. S. A., Sievenpiper, J. L., Barclay, A. W., Liu, S., Wolever, T. M. S., Willett, W. C., Brighenti, F., Salas-Salvadó, J., Björck, I., Rizkalla, S. W., Riccardi, G., Vecchia, C. L., Ceriello, A., Trichopoulou, A., Poli, A., Astrup, A., Kendall, C. W. C., Ha, M. A., Baer-Sinnott, S., \& BrandMiller, J. C. (2019). Dietary glycemic index and load and the risk of type 2 diabetes: assessment of causal relations. Nutrients Journal, 11(6), 1436. http://dx.doi.org/10.3390/nu11061436. PMid:31242690.

Mann, J., Cummings, J. H., Englyst, H. N., Key, T., Liu, S., Riccardi, G., Summerbell, C., Uauy, R., van Dam, R. M., Venn, B., Vorster, H. H., \& Wiseman, M. (2007). FAO/WHO scientific update on carbohydrates in human nutrition: conclusions. European Journal of Clinical Nutrition, 61(1, Suppl. 1), 132-137. http://dx.doi.org/10.1038/ sj.ejcn.1602943. PMid:17992184.

Nestares, T., López-Frías, M., Barrionuevo, M., \& Urbano, G. (1996). Nutritional assessment of raw and processed chickpea (Cicer arietinum L.) protein in growing rats. Journal of Agricultural and Food Chemistry, 44(9), 2760-2765. http://dx.doi.org/10.1021/jf950545q.

Onurlubaş, E., \& Taşdan, K. (2017). Geleneksel Ürün Tüketimini Etkileyen Faktörler Üzerine Bir Araştırma. Bolu Abant İzzet Baysal Üniversitesi Sosyal Bilimler Enstitüsü Dergisi, 17(1), 115-132.

Özdemir, S., Gocmen, D., \& Yildirim Kumral, A. (2007). A traditional Turkish fermented cereal food: Tarhana. Food Reviews International, 23(2), 107-121. http://dx.doi.org/10.1080/87559120701224923. 
Pekak, R., (2006). Bir ticari değirmende Kadayıflı un üretiminin optimizasyonu üzerine bir çalı̧̧ma (A study on optimization of Kadayıf flour production in a commercial mill) (Yüksek Lisans Tezi). Selçuk Üniversitesi Fen Bilimleri Enstitüsü, Selçuk.

Pereira, M. A., Swain, J., Goldfine, A. B., Rifai, N., \& Ludwig, D. S. (2004). Effects of a low-glycemic load diet on resting energy expenditure and heart disease risk factors during weight loss. Journal of the American Medical Association, 292(20), 2482-2490. http://dx.doi. org/10.1001/jama.292.20.2482. PMid:15562127.

Pfeiffer, A. F., \& Keyhani-Nejad, F. (2018). High glycemic index metabolic damage-a pivotal role of GIP and GLP-1. Trends in Endocrinology and Metabolism, 29(5), 289-299. http://dx.doi.org/10.1016/j. tem.2018.03.003. PMid:29602522.

Sayaslan, A., Akarçay, E., \& Tokatlı, M. (2016). Kavrulmuş Mısır, Buğday ve Nohut (Leblebi) Çerezlerinin Beslenme Açısından Önemli Karbonhidrat Fraksiyonları. Akademik Glda, 14(3), 284-292.

Topal, S., Çinar, N., \& Altinkaynak, S. (2016). Süt çocukluğu döneminde beslenme. Düzce Üniversitesi Sağlık Bilimleri Enstitüsü Dergisi, 6(1), 63-70.
Topbaş Bıyıklı, E., Bıyıklı, A. E., \& Akbulut, G. (2017). Glisemik İndeks, Glisemik Yük ve Kanser. Beslenme ve Diyet Dergisi, 45(1), 70-76.

Türk Standartları Enstitüsü - TSE. (2004). TS 2282: Tarhana standardi. Ankara.

Türk Standartları Enstitüsü - TSE. (2010). TS 10443: Yufka-Böreklik (Necatibey Cad., No. 112, 6 p.). Ankara: Bakanlıklar.

Türk Standartları Enstitüsü - TSE. (2014). Pişmaniye standard detayi. Ankara.

Türk Standartları Enstitüsü - TSE. (2015). Türk baklavasi standardi. Ankara.

Turkey. (2009a). Ova un, bilateral discussion. Konya.

Turkey. (2009b). Onel un, bilateral discussion. Konya.

Turkey. (2009c, Şubat 16). Türk Gıda Kodeksi (TGK) Bulgur Tebliği (Tebliğ No: 2009/24). Resmî Gazete.

Turkey. (2013, Eylül 12). Türk Gıda Kodeksi (TGK) Bulgur Tebliği (Tebliğ No: 2013/55). Resmî Gazete.

Turkomp. (2020). Turkish food composition database (Vol. 1). Retrieved from http://www.turkomp.gov.tr/main 